
Enterprise Risk Management: A Case Study In Borsa Istanbul Stock Exchange*

\author{
Süleyman Serdar KARACA** \\ Zekai ŞENOL ${ }^{* * *}$ \\ Özge KORKMAZ ${ }^{* * * *}$
}

\begin{abstract}
Corporate governance and enterprise risk management (ERM) issues have become important issues such as the big corporate scandals following the Enron, the 2008 global economic crisis, the deepening of financial markets, the increase of shareholder numbers in firms and the importance of investor expectations. Some issues such as financial stability, sustainable growth and stakeholder responsibilities related to corporate governance increase the effectiveness of the ERM, taking by management of the risk response related to ERM, ensuring reasonable assurance of reaching objectives, managing risk reporting, etc. In this study, the interrelationships between ERM and corporate governance, which are two mutually influential subjects, were researched. In the logistic regression analysis of 231 companies and time samples for 2009-2015 period, it was seen that corporate governance and ERM positively influenced each other.
\end{abstract}

Keywords: Corporate Governance, Enterprise Risk Management, Panel Data Analysis, Panel Logit Model Jel Classification: G30, G32, C33

\title{
Kurumsal Yönetim İle Kurumsal Risk Yönetimi Arasındaki İlişki: Borsa İstanbul Örneği \\ ÖZET
}

Enron sonrasında devam eden büyük şirket skandalları, 2008 küresel ekonomik krizi, finansal piyasaların derinleşmesi, firmalarda hissedar sayılarının artması, yatırımcı beklentilerinin önem kazanması gibi konular gerek kurumsal yönetim gerekse kurumsal risk yönetimi (KRY) konularını önemli hale getirmiştir. Kurumsal yönetimle ilgili finansal istikrar, sürdürülebilir büyüme, paydaş sorumlulukları gibi bazı konular KRY’nin etkinliğini etkilerken, KRY ile ilgili risk yanıtının yönetimce alınması, amaçlara ulaşmada makul güvence sağlanılması, risk raporlamasının yönetime yapılması gibi konular kurumsal yönetim etkinliğini artırmaktadır. Bu çalışmada birbirini etkileyen iki konu olan kurumsal yönetim ile KRY'nin birbirlerine etkileri araştırılmıştır. 2009-2015 dönemine ait 231 firma ve zaman örnekleminde yapılan logistik regresyon analizinde kurumsal yönetim ile KRY'nin birbirlerini pozitif şekilde etkiledikleri görülmüştür.

Anahtar Kelimeler: Kurumsal Yönetim, Kurumsal Risk yönetimi, Panel Veri Analizi, Panel Logit Model. JEL Sinıflandirması: G30, G32, C33

\footnotetext{
${ }^{*}$ This study is derived from the development of the paper presented in the 4th International Accounting and Financing Symposium in Ohrid/Macedonia on 2-3 July 2017.

** Assoc. Prof. Süleyman Serdar Karaca., Gaziosmanpaşa University, Faculty of Economics and Administration Sciences, suleymanserdar.karaca@gop.edu.tr

${ }^{* * *}$ Assist. Prof. Zekai Şenol, Cumhuriyet University, Faculty of Economics and Administration Sciences, zsenol@cumhuriyet.edu.tr

${ }^{* * * *}$ Assist. Prof. Özge Korkmaz, Bayburt University, Faculty of Economics and Administration Sciences, okorkmaz@bayburt.edu.tr
} 


\section{INTRODUCTION}

Corporate governance debates continue until the early 1980s. Some of the business executives in the USA have not taken stockholder interests into account, but have turned to profit maximization instead of maximizing shareholder value. As a result of these initiatives, issues such as the participation of shareholders in decision-making processes, the social responsibilities of companies, their sustainability and business democracy have come to the fore (Top and Öge, 2012: 105).

Many global corporate bankruptcies have begun to evolve, along with scandals in Bristol-Myers, Squibb, Qwest, Xerox, WorldCom, Global Crossing and other companies that have been in the aftermath of the Enron collapse. With these events, concepts such as transparency of companies, consideration and protection of investor and stakeholder expectations, and ensuring sustainability of companies have begun to take more place in business and economics.

In parallel with the development and deepening of financial markets, business ownership and business management concepts have been separated and businesses have started to be managed by professional managers in order to provide the interests of business stakeholders, primarily shareholders. Past experience has revealed that business executives are deficient in fulfilling their responsibilities to stakeholders.

Today, shareholders form the board of directors in general boards to manage company activities. The board of directors transfers the executive authority to the company's CEO, who is professional in this regard. The responsibility of the Company CEO is the board of directors, who is responsible to both the individual and the collective shareholders. In this way, the authority transfer system is called corporate management. The purpose of corporate governance is to determine the rights and obligations of business stakeholders and to provide investor trust (Özsoy, 2011: 48).

Corporate governance is a management approach based on concepts such as accountability, responsibility, public disclusure and transparency. Corporate governance does not only include shareholders and managers, but also customers, suppliers and creditors (Bask1c1, 2015: 164). The goal of corporate governance is to help create an atmosphere of trust, transparency and accountability necessary to develop long-term investments, financial stability and the honesty of businesses, and to support stronger and more inclusive societies on this end (G20 / OECD, 2016:7).

In companies where the number of shareholders is large in number and shareholder shares are relatively small, it is frequently stated that top managers are excessively strong and that the audit of fulfilling their duties and responsibilities is weak (Doğan, 2007: 40).

In the mid-1990s, ERM emerged as a new approach to risk management and thinking in an understanding of how to deal with risks in modern risk management (Kleffner et al., 2003: 54, Simkins and Ramirez, 2008: 580; Fraser et al., 2015: 1 ). This new understanding and thinking has been expressed as strategic risk management, enterprise level risk management, holistic risk management, integrated risk management and finally the most compromised concept of enterprise risk management. 
The concept of risk management joined the concept of corporate governance in the late 1990s. The concept of corporate governance has evolved since the late 1980s as a result of reaction of corporate scandals in the United States and the United Kingdom. These scandals and losses have helped to significantly increase the scope and depth of existing regulations in operational risk management (Merna and Al-Thani, 2008: 269).

Despite having a long history of risk management for many organizations, the 20082009 global economic and financial collapse has demonstrated the necessity of ERM, in general for healthy organization structure and long-term sustainability (Hardy, 2015: 27). In the past, many organizations have dealt with risks in silos, focusing narrowly on insurance, exchange rates, operations, credit and manufactured products, and risk management in the form of separate activities. All risks under ERM conditions are being implemented as part of an integrated, strategic and institution-wide system (Fraser and Simkins, 2010: 3). ERM includes methods and processes used by organizations to minimize surprises and capture opportunities related to achieving of organizations'goals (Marchetti, 2012: 1).

ERM is a process, effected by an entity's board of directors, management and other personnel, applied in strategy setting, and across the enterprise, designed to identify potential events that may affect the entity, and manage risk to be within its risk appetite, to provide reasonable assurance regarding the achievement of entity objectives (COSO, 2004: 4).

Corporate governance is the most important aspect of developing an economic activity that balances the relationship between the management of an enterprise, its board of directors, its shareholders and other stakeholders. ERM is the core component of corporate governance (Demidenko and McNutt, 2010: 803). Corporate governance has a wide range of issues and risk management is an integral part of a successful corporate governance organization (Hopkin, 2010: 175). ERM is at least as important an element of corporate governance as internal control (TÜSİAD, 2008: 69). It is not right to evaluate ERM outside of corporate governance. In businesses where there is no corporate governance, it is not possible to talk about institutional risks. There is an intertwining between ERM and corporate governance (Bozkurt, 2010: 26).

Table 1. Relations Between Corporate Governance and Enterprise Risk Management

\section{A. The Effects of Corporate Governance on ERM}

1. Observance of public disclosure and transparency in the reporting of risks that affect business operations.

2. Providing good governance by taking into consideration all stakeholder expectations, including stakeholders, stakeholders, in the execution of the ERM process.

3. The board has responsibility for risk management.

4. Doing audits and controls in determination of risks and the implementation of risk decisions.

5. Corporate governance should ensure that business risks are better managed.

B. The Effects of ERM on Corporate Governance 
1. Reduced fluctuations and surprises in business operations.

2. Reporting the risks affecting the business activities to the board of directors and issuing the risk response decision by the management.

3. Risk management is implemented at the enterprise level on the entire enterprise.

4. ERM increased institutionalization in business.

5. Provide reasonable assurance of ERM's ability to reach the objectives set by the board of directors and management.

6. Considering the risks involved in taking business decisions and incorporating them into the decision-making processes of the ERM.

7. ERM is the key component of corporate governance

Corporate governance emerged from two main sources: (1) the practice of regulatory agencies and organizations; and (2) risk-based management (Carden et al., 2015: 137). It is necessary for the risk management to involve the whole of the enterprise, the involvement of the enterprise in decision making processes, the concern of all employees of the risk culture and risk philosophy, the importance of financial reporting and transparency in risk management and the necessity of good management practices of risk management in the end are situations that improve corporate governance.

ERM increases institutionalization in businesses as well as the ability to respond appropriately to risks (Simkins and Ramirez, 2008: 572). ERM provides practices and safeguards that are tailored to corporate governance procedures, the company's risk tolerance and risk appetite (The Conference Board, 2007: 13). The most important contribution of ERM in terms of corporate governance is to protect the interests of shareholders in a minimum level and to maximize shareholder value (TÜSİAD, 2008: 69).

At the beginning of the 2000s, regulations related to corporate governance were made as a result of scandals erupting in companies like Enron, Tyco, WorldCom, Parmalat. Legal regulations related to corporate governance; NYSE Corporate Governance Code (US), Sarbanes-Oxley (SOX) Act (United States), Corporate Governance Code (UK), Dutch Corporate Governance Act (Paape and Spekle, 2012: 538).

The G20 / OECD corporate governance principles, first published in 2004 and later updated and published in 2016, (1) Provision of bases for effective corporate governance framework; (2) Rights of shareholders, fair treatment and basic partnership functions; (3) Institutional investors, share markets and other intermediaries; (4) The role of stakeholders in corporate governance; (5) Public disclusure and transparency; (6) The responsibilities of the board of directors.

A similar arrangement was made in Turkey by the Capital Markets Board (CMB) as a Corporate Governance Principles. In the Communiqué, corporate governance responsibilities of the companies were expressed in four subjects as shareholders, transparency, transparency, interest holders and management boards. Accordingly, one of the committees that should be formed within the board of directors is the committee for the early detection of risks that will 
jeopardize the company's existence, development and continuity, taking necessary precautions related to the identified risks and risk management activities.

As stated in Table 1, there is a relationship between corporate governance and ERM. As seen in the literature, the number of studies examining the interaction between corporate governance and ERM is negligible. For this reason, this study is important in terms of eliminating this deficiency in the literature. The aim of this study is to explain the relationship between corporate governance and ERM in the sample of Stock Exchange Istanbul. The study consists of literature review, analysis and evaluation of the results.

\section{LITERATURE}

There are many studies in the academic literature based on corporate governance and / or ERM. In a significant part of these studies, the concepts of corporate governance and ERM were examined separately. Most of the studies related to corporate governance have tried to determine the effects of corporate governance and the determinants of corporate governance.

Studies by Mitton (2002), Drobetz et al. (2004), Bhadat and Bolton (2007), Switzer and Tang (2009), Karamustafa et al. (2009), Varshnedy et al. In the literature, on the other hand, studies to measure the effects of ERM on firm value and firm performance generally; Gordon et al. (2009), Pagach and Warr (2010), Sugarcia (2011), McShane et al. (2011), Hoyt and Liebenberg (2011), Bertinetti et al. (2013), Baxter et al. (2013), Li et al. (2014), Grace et al. (2015), and Farrell and Gallagher (2015). Beasley et al. (2005), Önder and Ergin (2012), Baxter and others (2013), Bertinetti et al. (2013) and Farrell and Gallagher (2015) for determining the factors affecting ERM applications, as well as Liebenberg and Hoyt (2003).

In addition to these, the studies that the corporate governance and ERM have taken together have been the subject of this study. The studies investigating the relationship between corporate governance and ERM and the effects on each other; (1) studies that are theoretical, theoretical, model proposals and qualitative evaluations (2) application and analysis studies. Studies in which qualitative assessments are made; Brown and others (2009), Demidenko and McNutt (2010), Boghean (2015) and Carden and others (2015). On the other hand, studies that are analyzed through numerical values and variables; Kleffner and others (2003), Brezeanu and others (2011), Akındele (2012), Paape and Spekle (2012) and Mandac1 and Kahyaoğlu (2012).

Kleffner et al. (2003) want to explain the use of ERM by Canadian companies, the characteristics associated with the use of ERM, the barriers that companies face in ERM practice, and the role that corporate governance plays in ERM implementation decisions. The study found that the Toronto Stock Exchange Rules affected the ERM usage strategies in Canada, and ERM applications were becoming more widespread. It has been suggested that when the perspective of the global marketplace is expanded in terms of the study, there will be differences between corporate governance standards, institutional cultures, and ERM practices at different markets. Therefore, it is suggested that corporate governance standards should be applied in different parts of the world and in different sectors.

Brown et al. (2009) investigated the relationship between risk management practices and corporate governance of high technology biotechnology firms in Australia. The underlying corporate governance structure of the work will enable companies to better 
manage the risks they face. In the study, a good corporate governance mechanism for high biotechnology firms is proposed to implement ERM by creating a separate risk management committee.

Demidenko and McNutt (2010) demonstrate the application of corporate governance and risk management practices in Russia and Ukraine and; the implementation of ERM, the key component of corporate governance, has been demonstrated as a way to improve risk management practices in businesses.

Brezeanu et al. (2011) used data generated from annual financial data for 1997-2007 from firms registered in NASDAQ to investigate the impact of corporate governance on enterprise-level risk management systems. Institutional investors, chief executive officer, dummy variables of block shareholders, regressions of firms using financial ratios as traditional financial indicators were found to be influenced by some of the variables used, which led to the conclusion that corporate governance affected risk management systems.

Akındele (2012) investigated the relationship between risk management and corporate governance on bank performance in Nigeria. In the analysis using the survey and the information obtained from the annual financial reports for the 2008-2009 period, better corporate governance led to better risk management and a positive relationship was found between corporate governance and risk management.

Paape and Spekle (2012) investigated the impact of corporate governance regulations on ERM application levels and found that regulatory changes related to corporate governance did not affect ERM development, while stock quotes affected the development of ERM systems.

Mandacı and Kahyaoğlu (2012) investigated the impact of corporate governance on corporate risk management using data from non-financial firms traded at the BIST. In the study, (1) the questionnaire applied to the company risk managers and (2) the data sources disclosed to the public were used. In the results obtained for 94 companies, the corporate governance did not affect the enterprise risk management

Boghean (2015), in the context of corporate governance practices, aimed to identify those who influence decision-making processes in terms of company resources, production methods, operating environment and decision support systems. In the study, it was thought that contribution to the development of information between risk management through decision-making processes in the context of effective corporate governance. It was seen that the results obtained in rational analyzes were mostly used by combining new trends with intuitions in making decisions of risk management by evaluating the survey results.

Carden et al. (2015) point out that in the theoretical and model studies on health and safety, employees are expected to establish safe working environments from the institutions, that the safe working environment is related to risk management practices and that these are part of the corporate governance and risk management processes. Followed by the Sarbanes Oxley (SOX) regulation, which requires regulatory measures to reduce health and safety risks in the same way risk management. 


\section{ANALYSIS}

In order to determine the relationship between corporate governance and ERM, samples were drawn from non-financial firms registered in the BIST. In the creation of the sample; (1) Incorporation into the BIST Corporate Governance index, (2) in the preliminary investigations conducted earlier, the Istanbul Chamber of Industry, prepared for the year 2015 by the Istanbul Chamber of Industry, BIST registered companies. The BIST Corporate Governance Index consists of the shares of companies whose ratings are at least 7 out of 10 by the rating agencies that are responsible for compliance with corporate governance principles.

Despite the fact that most audit committees are used as variable (Mandac1 and Kahyaoğlu, 2012; Akındele, 2012; Paape and Spekle, 2012) representing the corporate governance in the literature, there are not many similarities in terms of the variables used. Mandacı and Kahyaoğlu (2012), representing the corporate governance practices, audit committee and corporate governance committee; Brezeanu et al (2011), corporate investors, CEO presence and block shareholders; Akındele (2012), audit committee, corporate governance policies and practices; Paape and Spekle (2012) used corporate governance regimes, audit committee, institutional ownership, and firm owners at the same time as managers.

In previous studies, different methods have been used to determine and measure firms' ERM applications. (1) Bertinetti et al. (2013) and Pagach and Warr (2010) used a Chief Risk Officer (CRO) in company management. Florio and Leoni (2016) used ERM to represent board independence with CRO appointment, internal control and risk committee. (2) Hoyt and Liebenberg (2011) used the information obtained from financial reports on behalf of ERM. (3) Şekerci (2011) measured the ERM applications with the information they obtained from the questionnaire they prepared. (4) McShane et al. (2011) used ERM ratings, which S \& P has used since 2007 as a representative of ERM. (5) Gordon et al. (2009) conducted ERM studies through the ERM index they created.

The variables used in the study are shown in Table 1. Companies' ERM and corporate governance practices are used as dummy variables. Variables that can not be measured but can be counted in regression models are called dummy, shadow, or dummy variable. Dummy variables are transformed into countable variables by assigning specific values to unmeasured variables (Dikmen, 2012: 155). Among the regressions in which dummy variables are used as dependent variables are logit models.

$$
L_{i}=\log \left(\frac{P_{i}}{1-P_{i}}\right)=\beta_{1}+\beta_{2} X_{1}+\mu_{i}
$$

Where $\mathrm{Pi}=1$ if something is present, and $\mathrm{Pi}=0$ if it is not. It is found as follows;

$$
\begin{aligned}
& L_{i}=\log \left(\frac{1}{0}\right) \text { if something is present } \\
& L_{i}=\log \left(\frac{0}{1}\right) \text { if it is not }
\end{aligned}
$$

Corporate governance variable has been formed as "1" or "0" according to the inclusion in the BİST Corporate Governance index. ERM variables are assigned as "0" for 
companies that do not have ERM application "1" in line with the information obtained from the detailed examination of the company's annual reports.

In the study, panel data analysis was done because it is units (firms) and time (years). The panel data regression is generally expressed as:

$$
y_{i t}=\alpha+X_{i t} \beta+\mu_{i t} i=1, \ldots \ldots, N, t=1, \ldots \ldots, T
$$

Where; i represent businesses, households, individuals, countries and so on. $\mathrm{i}$ is the index section size, and $\mathrm{t}$ is the time serial dimension. A scalar, $\beta ; \mathrm{Kx} 1$ dimensional parameters are the column vector, and $X_{i t}$ is the observation value at time $t$ in the $i$ the unit for $K$ explanatory variables. $U_{i t}$ is the error term at time $t$ of the $i_{\text {th }}$ unit (Baltagi, 2005: 11).

Leverage (LEV), profitability (ROA) and size variables (LOGSIZE) are the control variables used in the study. In order to determine the effect of corporate governance on ERM, the following panel logit model was created. LOGSIZE, LEV and ROA are the control variables that are expressed and determined to have an effect on ERM and corporate governance in the literature.

$$
E R M_{i t}=\beta_{0}+\beta_{1} C_{\text {ORGOVERN }}+\beta_{2} \text { LOGSIZE }_{i t}+\beta_{3} L E V_{i t}+\beta_{4} R O A_{i t}+\mu_{i t}
$$

The following panel logit model was used to determine the effect of ERM on corporate governance using the above control variables

$$
\operatorname{CORGOVERN~}_{i t}=\beta_{0}+\beta_{1} \mathrm{ERM}_{i t}+\beta_{2} \mathrm{LOGSIZE}_{i t}+\beta_{3} L E V_{i t}+\beta_{4} R O A_{i t}+\mu_{i t}
$$

Table 2. Variables Used and Explanations

\begin{tabular}{|l|c|l|}
\hline $\begin{array}{c}\text { Variables and } \\
\text { Abbreviations }\end{array}$ & $\begin{array}{c}\text { Abbreviation of } \\
\text { Variables }\end{array}$ & \multicolumn{1}{|c|}{ ExplainingVariables } \\
\hline ERM Application & ERM & $\begin{array}{l}\text { ERM if Applied “1”, if not } \\
\text { applied “0” }\end{array}$ \\
\hline CorporateGovernance & CORGOVERN & $\begin{array}{l}\text { CORGOVERN if Applied “1”, } \\
\text { if not applied “0” }\end{array}$ \\
\hline Company Size & LOGSIZE & $\begin{array}{l}\text { Natural Logarithm of Total } \\
\text { Assets }\end{array}$ \\
\hline Financial Leverage & LEV & Total Debt/Total Assets \\
\hline Return on Assets & ROA & Net Profit/Total Assets \\
\hline
\end{tabular}

The summary statistics for the variables used in the study are in Table 3. It is seen that 231 firms and about half of the time observation value are applied by ERM, 29\% of the firms are included in the corporate governance index and the average of the leverage ratios is in the leverage stand. 
Table 3. Summary Statistics

\begin{tabular}{|lccccc|}
\hline & Obs. & Mean & Std. Dev. & Min. & Max. \\
\hline ERM & 231 & 0.4935065 & 0.5010435 & 0 & 1 \\
\hline CORGOVERN & 231 & 0.2943723 & 0.4567498 & 0 & 1 \\
\hline LOGSIZE & 231 & 21.07508 & 1.198366 & 16.88936 & 23.83085 \\
\hline LEV & 231 & 0.5121941 & 0.1903641 & 0.053075 & 0.912891 \\
\hline ROA & 231 & 0.0543444 & 0.071098 & -0.216227 & 0.344859 \\
\hline
\end{tabular}

Table 4 shows the correlation coefficients between the variables used in the study. There is a positive correlation between corporate governance (CORGOVERN) and ERM, and this correlation seems to be meaningful. Among the variables used in the study, there is no correlation that affects the model formation negatively.

Table 4: Pearson Correlation Coefficients

\begin{tabular}{|c|c|c|c|c|c|}
\hline & ERM & $\begin{array}{l}\text { CORGO } \\
\text { VERN }\end{array}$ & LOGSIZE & ROA & LEV \\
\hline ERM & 1 & $\begin{array}{l}0,217^{* *} \\
(0,001)\end{array}$ & $\begin{array}{l}0,387^{* *} \\
(0,000)\end{array}$ & $\begin{array}{c}0,164^{*} \\
(0,013)\end{array}$ & $\begin{array}{c}0,043 \\
(0,512)\end{array}$ \\
\hline CORGOVERN & & 1 & $\begin{array}{l}0,436^{* *} \\
(0,000)\end{array}$ & $\begin{array}{c}-0,024 \\
(0,, 712)\end{array}$ & $\begin{array}{c}0,133^{*} \\
(0,044)\end{array}$ \\
\hline LOGSIZE & & & 1 & $\begin{array}{l}-0,067 \\
(0,311)\end{array}$ & $\begin{array}{l}0,247^{* *} \\
(0,000)\end{array}$ \\
\hline ROA & & & & 1 & $\begin{array}{l}-0,316^{* *} \\
(0,000)\end{array}$ \\
\hline LEV & & & & & 1 \\
\hline \multicolumn{6}{|c|}{$\begin{array}{l}\text { Note: The first values in the table cells indicate the Pearson coefficient, and the ** } \\
\text { and * indicate significance levels of } 0.01 \text { and } 0.05 \text { respectively }\end{array}$} \\
\hline
\end{tabular}

The panel comes from the data units and from time to time. For this reason, it is necessary that the data constituting the panel data are in the unit root, that is, they are stationary. Table 5 shows the results of 1st Generation unit root test applied in panel data analysis. Leverage (LEV) and profitability (ROA) variables are stable in most of the tests, while size variance (LOGSIZE) is not.

Table 5. Panel Unit Root Tests (I. Generation - None Trend)

\begin{tabular}{|l|l|l|l|l|l|l|}
\hline \multirow{2}{*}{} & \multicolumn{2}{|c|}{ Levin, Lin and Chu } & \multicolumn{2}{c|}{ Breitung } & \multicolumn{2}{c|}{ Im, Pesaran and Shin } \\
\cline { 2 - 7 } & Level & 1st Diff & Level & 1 st Diff & Level & 1 st Diff \\
\hline LOGSIZE & $-4.26571^{* * *}$ & & 0.97396 & $-2.92505^{* * *}$ & 3.38215 & $-3.40639 * * *$ \\
\hline LEV & $-6.80523 * * *$ & & 0.54946 & $-2.82642^{* * *}$ & -0.58920 & $-4.46879 * * *$ \\
\hline
\end{tabular}


The Journal of Accounting and Finance

April/2018

\begin{tabular}{|l|l|l|l|l|l|l|l|}
\hline \multirow{2}{*}{ ROA } & $-7.65974^{* * *}$ & & -0.11598 & $-1.72904^{* *}$ & $-1.38290^{*}$ & \\
\hline & \multicolumn{3}{|c|}{ Fisher ADF } & \multicolumn{2}{|c|}{ Fisher PP } & \multicolumn{2}{|c|}{ Hadri } \\
\cline { 2 - 7 } & Level & 1 st Diff & Level & 1 st Diff & Level & 1 st Diff \\
\hline LOGSIZE & 4.65828 & $-4.81504^{* * *}$ & 5.40686 & $-6.24158^{* * *}$ & $10.4324^{* * *}$ & \\
\hline LEV & -1.24679 & $-5.31451^{* * *}$ & $-2.57886^{* * *}$ & & $8.22531^{* * *}$ & \\
\hline ROA & $-2.67147^{* * *}$ & & $-3.44469^{* * *}$ & & $6.60379^{* * *}$ & \\
\hline
\end{tabular}

In the panel data analysis, LR (Likelihood-ratio) test is performed for acceptance or rejection of the classical model. The classical model was rejected because of unit effects in LR tests. Hausman test is used to decide between fixed and random effect models (YerdelenTatoğlu, 2013: 187). The Hausman test showed that the random effect models were valid.

Table 6 shows the regression results. Accordingly, it is seen that the effect of corporate governance on ERM is economically and statistically significant. It has been determined that corporate governance positively affects ERM implementations.

Table 6: Logistic Regression Result (Random Effect Models)

\begin{tabular}{|c|c|c|c|c|c|c|c|c|}
\hline \multicolumn{5}{|c|}{ The Effect of CORGOVERN on ERM } & \multicolumn{4}{|c|}{ The Effect of ERM on CORGOVERN } \\
\hline & Coef. & $\begin{array}{l}\text { Std. } \\
\text { Err. }\end{array}$ & Z & $\mathrm{P}$ & Coef. & $\begin{array}{l}\text { Std. } \\
\text { Err. }\end{array}$ & $\mathrm{Z}$ & $\mathrm{P}$ \\
\hline ERM & & & & & 9.3322 & 2.4337 & 3.83 & 0.000 \\
\hline $\begin{array}{l}\text { CORGOV } \\
\text { ERN }\end{array}$ & 2.7150 & 1.0076 & .69 & 0.007 & & & & \\
\hline LEV & 3.2670 & 2.4529 & 1.33 & 0.183 & -17.353 & 8.5845 & -2.02 & 0.043 \\
\hline ROA & 6.2480 & 4.4256 & 1.41 & 0.158 & -19.310 & 24.276 & -0.80 & 0.426 \\
\hline dLOGSIZE & 7.1896 & 8.9126 & 0.81 & 0. & 7.1896 & 8.9126 & 0.81 & 0.420 \\
\hline Sabit & -2.5319 & 1.5665 & -1.62 & 0.106 & -13.761 & 5.8139 & -2.37 & 0.018 \\
\hline $\begin{array}{l}\text { Number of o } \\
\text { Wald chi2 } \\
\text { Hausman chi } \\
\text { LR chi2_c }\end{array}$ & $\begin{array}{l}198 \text { Nun } \\
=8,70 \\
1)=9.02( \\
187\end{array}$ & $\begin{array}{l}\text { er of gro } \\
\text { Prob }>= \\
\text { ob }>\text { chi2 }\end{array}$ & $\begin{array}{l}\text { Ps : } \\
\text { hibar } \\
=\quad 0\end{array}$ & $\begin{array}{l}0.000 \\
5)\end{array}$ & $\begin{array}{l}\text { Number of } \\
33 \text { Wald ch } \\
\text { Prob }>=\text { c } \\
\text { chi2(4) }=0 \\
\text { LR chi2_c }\end{array}$ & $\begin{array}{l}\text { obs: } 19 \\
2(4)=24 \\
\text { ibar2 = } \\
00 \text { (Prob } \\
174.400\end{array}$ & $\begin{array}{l}\text { Num. } \\
.000 \\
\text { i } 2=\end{array}$ & $\begin{array}{l}\text { gr. : } \\
\text { usman } \\
\text { 00) }\end{array}$ \\
\hline
\end{tabular}

As a result of the second regression, it is seen that ERM applications positively affected corporate governance and this effect is economically and statistically significant. These results show that corporate governance and corporate risk management interact positively with each other. Corporate governance and ERM's affirmation of each other positively supported the resultant theory. This is because issues such as the fulfillment of stakeholder expectations of corporate governance, the acquisition of investor trust, and the achievement of financial stability are also issues that support ERM applications. On the other 
hand, issues such as the taking of risk related decisions of ERM at institutional level, providing reasonable assurance of reaching business objectives, and transparency in reporting and decision making are also issues that increase the effectiveness of corporate governance. This result is most similar to the study of Akındele (2012) in the literature. Akındele (2012) study showed a positive relationship between corporate governance and ERM. Moreover, the result of corporate governance in the work of Brezeanu et al. (2011) positively affects the ERM, which is similar to the result of the positive effect of the corporate governance used in this study on ERM.

\section{RESULTS}

The big corporate scandals and global financial crisis in recent years have increased the importance of corporate governance and ERM concepts, and two studies and researches on corporate governance, ERM related business, regulatory organizations and universities have become widespread. It is not possible to distinguish between corporate governance and ERM concepts, and it is possible to say that the two concepts have increased their effectiveness by influencing each other.

In this study, it is aimed to determine the interaction between corporate governance and ERM in the sample of companies registered in BIST operating in Turkey in 2009-2015 period. In the panel logistic regression analyzes made, it was seen that both the corporate management affected on ERM and the ERM affected on the corporate governance positively.

\section{REFERENCES}

Akındele, R. I. (2012). Risk Managementand Corporate Governance Performance - Emprical Evidence from The Nigerian Banking Sector. IFEPsychologIA. 20(1), p. 103-120. 18p.

Baltagi, B. H. (2005). Econometric Analysis of Panel Data. England: John \&WileySons, Ltd.

Baskıcı, Ç. (2015). Kurumsal Yönetim Uygulamalarında İç Kontrol Sisteminin Önemi: Borsa İstanbul Şirketleri Üzerine Bir Araştırma. Uluslararası Yönetim İktisat ve İşletme Dergisi. 11(25): 163-180.

Baxter, R., Bedard, J. C., Hoitash, R and Yezegel, A. (2013). Enterprise Risk Management Program Quality: Determinants, Value Relevance, and the Financial Crisis. Contemporary Accounting Research. 30(4): 1264-1295.

Beasley, M. S., Clune, R., and Hermanson, D. R., (2005). Enterprise Risk Management: AN Emprical Analysis of Factors Associated with the Extent of Implementation, Journal of Accounting and Public Policy, 24: 521-531.

Bertinetti, G. S., Cavezzali, E. and Gardenal, G. (2013). The Effect of The Enterprise Risk Management Implementation on The Firm Value of European Companies, WorkingPaper Series, http://virgo.unive.it/wpideas/storage/2013wp10.pdf, (13.07.2014).

Bhadat, S. and Bolton, B. (2008). Corporate Governance and Firm Performance. Journal of Corporate Finance. 14(3), 257-273. 
Boghean, F. (2015). Researh on Risk Management, As Part of Corporate Governance, in Entities, The USV Annals of Economics and Public Administration. 15(Special Issue), 127-135.

Bozkurt, C. (2010). Risk, Kurumsal Risk Yönetimi ve İç Denetim. Denetişim Dergisi. (4): 17-30.

Brezeanu, P., Al Essaw1, M. S., Poanta, D. and Badea, L. (2011). Does Corporate Governance Impact Risk Management System? Theoretical and Applied Economics. 17(4), 49-64.

Brown, I, Steen, A. and Foreman, J. (2009). Risk Management in Corporate Governance: A Review and Proposal. Corporate Governance: An International Review, 17(5), 546558.

Carden, L. L., Boyd, R. O. and Valenti, A. (2015). Risk Management and Corporate Governance: Safety and Health Work Model. Southern Journal of Business and Ethics, Vol 7, 137-148.

Demidenko, E. and McNutt, P. (2010). The Ethics of Enterprise Risk Management as a Key Component of Corporate Governance. International Journal of Social Economics, 37(10), 802-815.

Dikmen, R. (2012) Ekonometri: Temel Kavramlar ve Uygulamalar. İstanbul Dora Yayınları.

Doğan, M. (2007). Kurumsal Yönetim. Ankara: Siyasal Kitabevi.

Drobetz, W., Schillhofer, A., and Zimmermann, H. (2004). Corporate Governance and Expected Stock Returns: Evidence from Germany. European Financial Management, 10 (2), 267-293.

Evrim Mandacı, P. and Bozkuş Kahyaoğlu, S. (2012). The Role of Internal Auditing and Corporate Governance in Enterprise Risk Management: Empirical Evidence on NonFinancial Firms Listed in Istanbul Stock Exchange. World of Accounting Science. 14(1), 43-66.

Farrell, M. and Gallagher, R. (2015). TheValuation Implications of Enterprise Risk Management Maturity, TheJournal of Risk and Insurance, 82(3): 625-657.

Florio, C. and Leoni, G. (2016) Enterprise Risk Management and Firm Performance: The Italian Case, The British Accounting Review.

Fraser, J. R. S., Simkins, B. J. and Narvaez, K. (Edit). (2015). Implementing Enterprise Risk Management: Cases Stuies and Best Practices. John \&Wiley Sons. Inc., New Jersey. U.S.A.

Fraser, J. and Simkins, B. J. (Edit). (2010). Enterprise Risk Management: Today’s Leading Research and Best Practices for Tomorrow's Executives, John Wiley\&Sons Inc., New Jersey, USA. 
Gordon, L. A., Loeb, M. P. and Tseng, C-Y. (2009). Enterprise Risk Management and Firm Performance Contingency Perspective, Journal of Accounting and PublicPolicy, 28(4): 301-327.

Gujarati, D. N. (2011). Temel Ekonometri. Çev. Ümit Şeneses ve Gülay Günlük Şeneses, İstanbul: Literatür Yayıncılık.

Hardy, K. (2015). Enterprise Risk Management: A Guide for Government Professionals, John Wiley\&Sons. Inc., San Francisco, USA.

Hopkin, P. (2010). Fundamentals of Risk Management: Understanding, Evaluating and Implementing Effective Risk Management. USA: KoganPage Limited.

Hoyt, R. E. and Liebenberg, A.P. (2011). The Value of Enterprise Risk Management. Journal of Risk and Insurance. 78 (4), 795-822.

Karamustafa, O., Varıcı, İ. and Er, B. (2009). Kurumsal Yönetim ve Firma Performansı: İMKB Kurumsal Yönetim Endeksi Kapsamındaki Firmalar Üzerinde Bir Uygulama. Kocaeli Üniversitesi Sosyal Bilimler Enstitüsü Dergisi. 17(1), 100 -119.

Kleffner, A. E., Lee, R. B. and McGannon B. (2003). The Effect of Corporate Governance on the Use of Enterprise Risk Management: Evidence from Canada. Risk Management and Insurance Review. 6(1), 53-73.

Kleffner, A. E., Lee, R. B. and McGannon, B. (2003). The Effect of Corporate Governance on the Use of Enterprise Risk Management: Evidence from Canada. Risk Management and Insurance Review, 6(1): 53-73.

Marchetti, A. M. (2012). Enterprise Risk Management: From Assessment toCompliance. John Wiley\&Sons. New Jersey. USA.

McShane, M. K.,Nair, A. and Rustambekov, E. (2011). Does Enterprise Risk Management Increase firm Value? Journal of Accounting, Auditing \& Finance. 26 (14): 641-658.

Merna, T. and AL-Thani, F. F. (2008). Corporate Risk Management. John Wiley\&Sons Ltd. England.

Mitton, T. (2002). A Cross-Firm Analysis of the Impact of Corporate Governance on the East Asian Financial Crisis. Journal of Financial Economics. 64, 215-241.

OECD (2016). G20/OECD Principles of Corporate Governance (TurkishVersion). OECD Publishing. Paris.

Önder, Ş. and Ergin, H., (2012), Determiners of Enterprise Risk Management Applications in Turkey: An Empirical Study with Logistic Regression Model on The Companies in ISE(IstanbulStocks Exchange), Business and Economic Horizons, 7(1): 19-26

Özsoy. Z. (2011). Kurumsal Yönetim ve Yönetim Kurulları. İmge Kitabevi: Ankara.

Paape, L. and Spekle, R. F. (2012). The Adoptionand Design of Enterprise Risk Management Practices: An Empirical Study. European Accounting Review. 21(3), 533-564. 
Pagach, D. and Warr, R. (2010). The Effects of Enterprise Risk Management on Firm Performance. (26.10.2014).

http://papers.ssrn.com/sol3/papers.cfm?abstract_id=1155218,

Simkins, B. and Ramirez, S. A. (2008). Enterprise-Wide Risk Management and Corporate Governance. Loyola University Chicago Law Journal. 39(3): 570- 594.

Simkins, B. and Ramirez, S. A. (2008). Enterprise-Wide Risk Management and Corporate Governance. Loyola University Chicago Law Journal. 39(3): 570- 594.

Switzer L. N. and Tang, M. (2009). The Impact of Corporate Governance on the Performance of U.S. Small Cap-Firms. International Journal of Business. 14(4), 341-355.

The Committee of Sponsoring Organizations of the Treadway Commission-COSO. (2004). Enterprise Risk Management - Integrated Framework: ExecutivesSummary. Jersey City. U.S.A.

The Conference Board. (2007). Emerging Governance Practices In Enterprise Risk Management. Research Report. http://papers.ssrn.com/sol3/papers.cfm?abstract_id=963221, (26.10.2014).

Top, S. and Öğe, E. (2012). Yeni Ekonomide İşletmelerin Kurumsallaşması ve Kurumsallaşmanın Boyutları. Yeni Ekonomi. İstanbul: Beta Basım.

Türk Sanayicileri ve İşadamları Derneği-TÜSİAD. (2008). Kurumsal Risk Yönetimi. İstanbul: Yayın No 452.

Yerdelen Tatoğlu, F. (2013). İleri Panel Veri Analizi: Stata Uygulamalı. 2. Baskı. İstanbul. Beta Basim. 